\author{
AIR COMMAND AND STAFF COLLEGE \\ AIR UNIVERSITY
}

\title{
CHE:
}

\section{His Own Worst Enemy}

\author{
by \\ JOSEPH S. VALENTINO, Maj, USAF
}

\begin{abstract}
A Research Report Submitted to the Faculty
In Partial Fulfillment of the Graduation Requirements for the Degree of
\end{abstract}

MASTER OF OPERATIONAL ARTS AND SCIENCE

\author{
Advisor: Lt Col Duane D. Gunn \\ Maxwell Air Force Base, Alabama
}

April 2015 


\section{Disclaimer}

The views expressed in this academic research paper are those of the author(s) and do not reflect the official policy or position of the US government or the Department of Defense. In accordance with Air Force Instruction 51-303, it is not copyrighted, but is the property of the United States government. 


\section{Table of Contents}

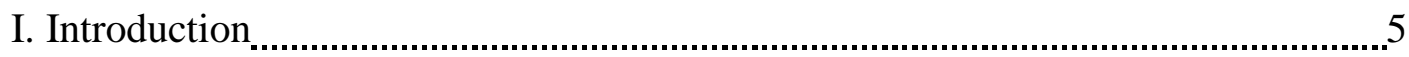

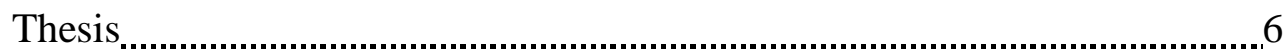

II. Why Bolivia

Domestic Climate

Bolivia

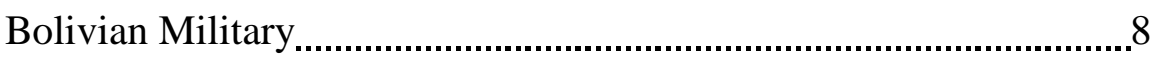

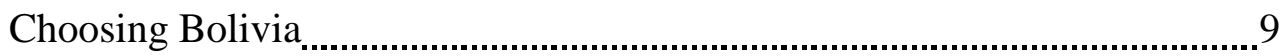

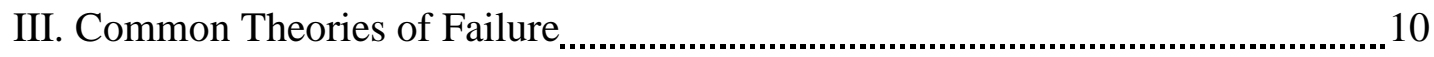

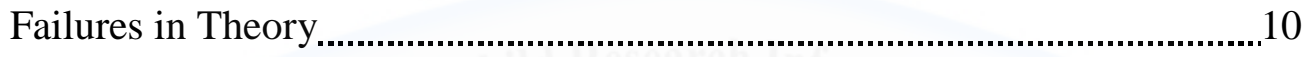

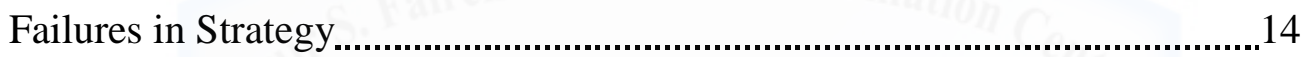

Failures in Tactics

Summary

IV . Finding the Root Cause

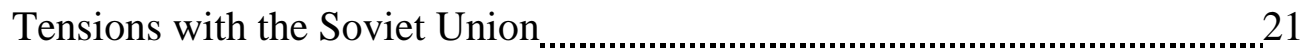

Soviet Policy toward Third World and Latin America .......................21

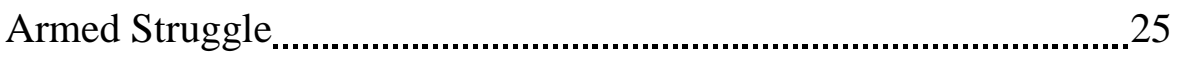

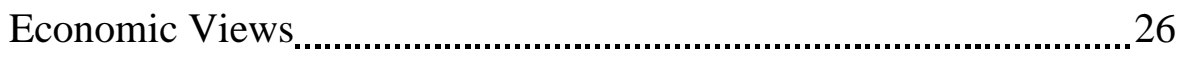

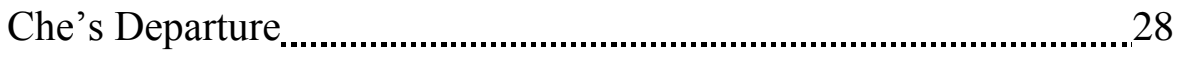

Effects in Bolivia during 1967......................................................................30

Bolivian Communist Party ................................................................. 30

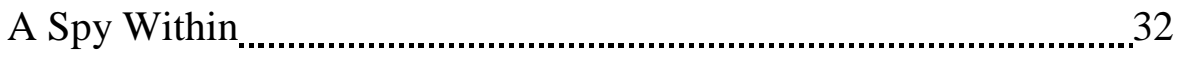

The Connection $\ldots$ 


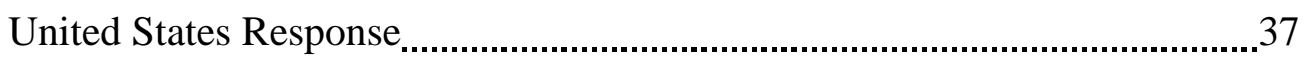

V. Conclusion

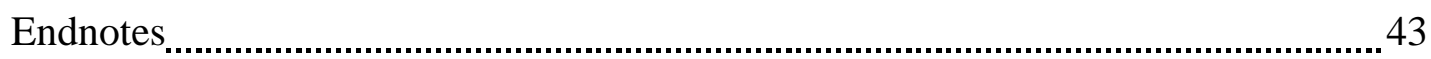

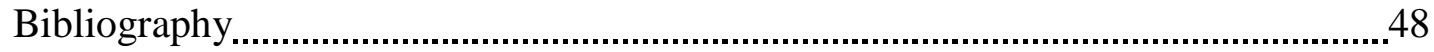




\section{Introduction}

World War II (WWII) not only left the international community recuperating from years of brutal war, but would also usher in a new age of revolutionary warfare. The weakening of colonial powers due to WWII effects would deteriorate their control over colonies or semicolonies. This diminishing of colonial powers ruling would give way to a rise in nationalism in many states, which sparked new revolutions in the post-WWII era. ${ }^{1}$ At the same time the world would witness to the emergence of the Cold War. As tensions intensified with the Cold War, both the Soviet Union and the United States sought beneficial relationships with emerging states or new governments to support their position. These efforts fueled some of the tensest events of the Cold War, but also supported the fanning flames of revolutionary fire burning throughout the world. This new threat was not confined to a specific state, region, or continent. The rekindling of revolutionary warfare mentality was felt globally, to include South America. Arguably the most widely known instance of revolutionary warfare in the western hemisphere was that which took place in Cuba from 1956-1959. ${ }^{2}$ The success of this revolution would spawn multiple revolutions in Latin America, some successful while others were failures. One such specific case was the attempted 1967 Bolivian revolution, which was spearheaded by the legendary Ernesto Che Guevara (Che). ${ }^{3}$ Che drew from his experience in the Cuban revolution, along with lessons learned from his trips to other states while employed by the Cuban government, in an attempt to spark insurrection in Bolivia. Che believed he could transplant the Cuban revolution model to Bolivia, and further hoped it would grow and spread further countries in Latin America. Although achieving some early successes, his efforts would ultimately fail and cost Che the ultimate price, his life. 


\section{Thesis}

There are varying views as to the cause of defeat by Che's guerrilla band in Bolivia. The outcome indisputably suggests that Che's efforts were unsuccessful, but how could his efforts fail in Bolivia if they were modeled and replicated of those used in the Cuban Revolution? The research conducted suggests that Che made many mistakes, from the strategic to tactical levels in the realm of military perspective. When researching Che's Bolivian campaign of 1967, often the tendency is to explain Che's failure through a purely military lens, specifically using Che's guerrilla warfare manual as a blueprint to contrast against the actual events. The conclusions drawn using this perspective typically limit their analysis mainly to the events in Bolivia in 1967.

This approach is not necessarily wrong; however it fails to adequately explain why Che would deviate from his own guerrilla warfare methodology. Their purposed causes of failure seemingly fall short of explaining a specific catalyst that drove the failures they describe. This paper will not strive to try and explain why this is, but will instead offer a theory to explain the cause of Che making mistakes contradictory to his guerrilla warfare manual. This paper purposes that root cause of Che's failure was his unbreakable adherence to his revolutionary ideology, or pride if you will. Che's unwavering belief that he knows best, would spark a chain of events that would become irreversible and doom the outcome of his 1967 Bolivian campaign.

\section{Why Bolivia}

Before examining the events of 1967 , it is first imperative to examine the variables that influenced the decision of Che and his associates in choosing Bolivia. Before discussing these causes, one must consider the domestic climate. Examining the existing domestic climate sheds light on the issues surrounding the suggested issues for failure. This environment would ultimately lead Che Guevara in his choosing of Bolivia to begin what he believed to be a 
continental guerrilla "foco". ${ }^{4}$ Only after examining the existing domestic climate, which enables a better understanding of the decision of why Bolivia was chosen, will one better understand the suggested causes of failure.

\section{Domestic Climate}

\section{Bolivia}

Like many other countries, Bolivia is rich in history for those wishing to study it. The vast history of Bolivia is not however, the concern here. Here the focus will be specifically reviewing the Bolivian climate from 1951 to 1967. Although a short period of time, Bolivia experienced much turmoil. This turmoil eventually culminated in the death of Che and the majority of his guerrilla band. The revolution that occurred in Bolivia in 1952 is one such example of the turmoil this country faced. This revolution has value to this discussion because of the goals it sought to obtain. The three main goals were: 1) nationalization of mining, 2) agrarian reform, and 3) universal suffrage. ${ }^{5}$ The masses ultimately weakened the military forces, toppling the ruling military government and starting on the path to reform. ${ }^{6}$ Bolivia was for a time showing signs of stabilization.

By 1964, Bolivia had experienced over a decade of consistent leadership. The Bolivian president (Dr. Paz Estenssoro) was re-elected in 1964, due significantly to his vice-president running mate (General Rene Barrientos) who ensured the support of both the military and campesinos (peasants). ${ }^{7}$ Aware of the dangers posed by communism, the two parties (Barrientos and campesino) agreed to deny any communist access to the campesino sectors in an attempt to defend Bolivian national values. ${ }^{8}$ Hopes of stabilizing dimmed in 1964 when internal politic party conflicts lead to violence, causing military involvement to quell the unrest. ${ }^{9}$ The results of which again placed the military into power..$^{10}$ The removal of the elected president went 
unopposed as the military had garnered the support of all the political leaders, and still enjoyed considerable support for the majority campesinos (peasant) sectors. ${ }^{11}$ Military control would last until 1966 when Bolivia made progress towards a constitutional framework by holding elections. ${ }^{12}$ Rene Barrientos (former vice-president) would be elected president due largely to support from the campesinos and urban middle class, but also enjoyed significant support from the Bolivian military forces. ${ }^{13}$

\section{Bolivian Military}

The Bolivian armed forces were scantly equipped and inadequately trained in the 1950s and 1960s. ${ }^{14}$ In some circles the Bolivian forces were called the worst of South America. ${ }^{15}$ Utilizing pre-World War II equipment, Bolivia began refitting its forces in 1954 through agreements established with the United States. ${ }^{16}$ These agreements were not only valuable to Bolivia for updating their antiquated equipment, but it also presented them with training opportunities. Once such opportunity was in 1962 when the United States deployed a detachment of Special Forces to Bolivia to support training efforts. ${ }^{17}$

Similarly the United States sponsored the Conference of Army Chiefs from the Americas. ${ }^{18}$ The intent of the conference was to address the concerns of the activities of Fidel Castro. The conference would allow countries to share information, coordinate doctrine, discuss joint action, and internal security to name a few. ${ }^{19}$ These conferences would prove vital to Bolivia, as Bolivian military leadership would use them to strengthen their relations with the United States through them. An example of this was in 1964 when the Bolivian military, once again, was in power and received substantial support from the Pentagon. ${ }^{20}$ The United States would continue to support Bolivia with military assistance as the concern of spreading 
communism grew and because as General Porter said during his visit to Bolivia, “...because the

assistance is properly utilized and Bolivia is capable to confront, if required, guerrilla activity." 21

\section{Choosing Bolivia}

As has already been briefly discussed, Che was instrumental in pushing an agenda that included the development of a continental guerilla "foco" within the confines of South America. ${ }^{22}$ This idea was expressed in 1966 at the Tricontinental Conference held in Havana in which Che expressed his objective of creating a second and/or third Vietnam in South America. ${ }^{23}$ In this spirit South America had experienced insurrections in Guatemala, Columbia, Venezuela, and saw the beginnings of it in Brazil and Bolivia by the summer of $1967 .{ }^{24}$ With so much activity ongoing, the decision on where to base the "foco" came down to either Peru or Bolivia. ${ }^{25}$ Peru would be ruled out largely due to an attempted armed struggle that had failed. ${ }^{26}$ This consequently left Bolivia.

This is not to say that Bolivia was blindly chosen as the potential "foco" in Che's eyes. There are many reasons why Bolivia was deemed suitable for the intentions sought. Once such reason for this is that Bolivia's geopolitical position would allow guerrilla efforts the option to spread into as many as five bordering countries. ${ }^{27}$ Another reason was the perception that the people were unhappy with existing government. There was a perception that repression existed in Bolivia and that the aspirations of the people was not being satisfied causing tensions to rise. ${ }^{28}$ Violent confrontations where taking place between the government and workers. ${ }^{29}$ Combine this with the perception Che held of the Bolivian government, being he saw it as comparable to the Cuban government he fought in the 1950s Cuban revolution, and one can see that Bolivia was fertile ground to Che and his supporters. ${ }^{30}$ 


\section{Common Theories of Failures}

Looking back on any past event, it is very easy to establish the issues and see the mistakes that were made. Such is the case with Che Guevara and Bolivia in 1967. Clearly there were mistakes and bad luck involved as Che would fatefully pay the ultimate price in the pursuit of his vision. There are common threads that are shared by those who have examined this event that point to the possible root cause of failure. The reasons range from bad theory, to flawed strategy, down to poor tactical execution. The following section will examine and discuss several of the more prevalent reasons suggested for Che's failure in Bolivia in 1967.

\section{Failures in Theory}

To begin it is prudent to examine the theory behind Che Guevara. Reading Che's "Guerrilla Warfare" book, he begins with the essence of guerrilla warfare by addressing three fundamental lessons learned from the Cuban revolution. These three fundamentals are: 1) Popular forces can win a war against the army, 2) It is not always necessary to wait until all conditions for the revolution are in place; the insurrectional foco can create them, and 3) In underdeveloped Latin America the fundamental setting for armed struggle is the countryside. ${ }^{31}$ There have been several challenges to the credibility of this theory of strategy. To the first point, it has been suggested that this is a rare occurrence. Since Castro had taken power in Cuba, there has only been on instance of this in Nicaragua in 1979 (a decade after Che's death). ${ }^{32}$ Even then it is argued that Somoza's Army in Nicaragua, similar to that of Batistia's before Castro in Cuba, did not possess any sense of national spirit ${ }^{33}$ and therefore did not identify with the populace's aspirations. ${ }^{34}$ The conclusion made is that a popular force defeating an established army with any regularity had yet to be proven. 
Similarly, the second of Che's theories is yet another idea that has drawn criticism for not being validated. It has not been disputed that there were multiple attempts to develop insurgencies throughout Latin America during this time period. However, depending on the side of the fence one is drawn to, it is suggested that these attempts did not come to fruition in developing the continental foco that Che had envisioned. ${ }^{35}$ It has been argued that instead of inflicting the suffering on the intended oligarchies, that these attempted insurgencies instead caused suffering to those with whom they sought support, the workers and campesinos (peasants). ${ }^{36}$ The long term effect then was not what was sought, creating conditions for revolution, but instead induced a degree of political and social disorientation that presented challenging problems to future Bolivian governments. ${ }^{37}$

Che's third point has been challenged with the assertion that Latin America in general was experiencing a migration of people from rural areas to urban areas. ${ }^{38}$ This migration it is argued was caused by economic conditions. To thwart this movement, it has been stated that the governments were introducing incentives to sway people to stay in rural, or agricultural, areas. ${ }^{39}$ The argument purposed then, is that the government in order to mitigate migration was attempting to improve conditions in agricultural areas, in some instances through agrarian reform. Despite these attempts however, it is argued that agriculture was diminishing in importance to nations' economies, thus any grievances pertaining to it were very minimal. ${ }^{40} \mathrm{It}$ would appear to be obvious then that the countryside Che spoke of may not have been as ideal as he once thought. Unfortunately this would not be the only issue some have argued contributed to Che's failure on a theoretical level.

Another oversight in theory that has been argued as contributing to Che's failure is derived from Che's own words. In Che's book “Guerrilla Warfare” he states: 
Where a government has come into power through some form of popular vote, fraudulent or not, and maintains at least an appearance of constitutional legality, the guerrilla outbreak cannot be promoted, since the possibilities of peaceful struggle have not yet been exhausted. ${ }^{41}$

Knowing that these words are from Che's own book, one has to ask themselves why Che and others would perceive Bolivia as not having fit the above statement. Although Bolivia's government, headed by Rene Barrientos, was not perfect, it was a constitutionally elected government that from all indications held popularity. ${ }^{42}$ All mechanisms of the government enjoyed some popular support and appeared to be functioning, to include Bolivia's Congress. ${ }^{43}$ By Che's own words then, armed struggle should not have been promoted. Instead the pursuit of peaceful means was warranted until these means had been exhausted. Only then, by Che's own theory, could armed struggle be promoted. This miscalculation appears to play into another reason why Che's efforts failed.

One overwhelming argument as to why Che's efforts failed in Bolivia was that the guerrillas never gained the support of the masses. In reading Che's book "Guerrilla Warfare" one will find numerous references to the masses. Again right at the beginning of Che's book he sets this premise when he states:

It is important to emphasize that guerrilla warfare is a war of the masses, a war of the people. The guerrilla band is an armed nucleus, the fighting vanguard of the people. It draws its great force from the mass of the people themselves. ${ }^{44}$

This quotation is just one excerpt from Che's book stressing how important the support of the masses is to guerrilla efforts. Without this support then, it is assumed that guerrilla efforts would fail. This is the argument that has been made in Che's case. It has been asserted that Che's guerrillas did not get this support because the people did not want to fight. ${ }^{45}$ Part of this argument is that the common citizen, or local populace in the area of operations, did not understand the guerrillas and therefore did not feel compelled to join their efforts. ${ }^{46}$ It has been 
suggested that this lack of understanding can be attributed to a breakdown in operations to mobilize this popular support. ${ }^{47}$

Further contributing to the isolation of the guerrillas was the lack of support garnered by the local (Bolivian) Communist Party. This stemmed from the perceived deception felt by Mario Monje, Communist Party general secretary in Bolivia ${ }^{48}$, who agreed to assist Che in the guerrillas in Bolivia believing they were for efforts to conduct operations outside of Bolivia. ${ }^{49}$ This would cause tension between the two groups. Another source of this tension was Monje's desire that a Bolivian lead the guerrilla efforts. ${ }^{50}$ Che refused to accept this stating in his diary "I had to be military chief and would not accept ambiguity on this." 51 This ultimately severed the ties between the guerrilla movement and the Bolivian Communist organization. Although this arguably had an impact on the guerrilla efforts, the much more significant issue was the lack of support amongst the masses.

Having lost the support of the Communist Party within Bolivia and only having had marginal success recruiting workers from the mines, the support of the campesinos was critical for a variety of reasons. This support was never achieved by Che and the guerrillas however, at least not to the extent Che had enjoyed in the Cuban revolution. It has been argued that part of the reason for this was due in part to the Agrarian Reform of 1953 which brought changes in land ownership and the social conditions of the campesinos (peasants). ${ }^{52}$ For example, by 1967 nearly 300,000 new land titles had been issued. ${ }^{53}$ Similarly the mining industry was prospering for the first time in over a decade despite various strikes. ${ }^{54}$ With conditions appearing to be positive for the targeted segment of the population Che was focused on for recruiting, it is not surprising that he was unable to garner the necessary support. Che even hints to doubts in his Bolivian diary that this core group, the campesinos, would join his efforts. ${ }^{55}$ 
Not only was Che unable to gain support of the masses, but there are arguments suggesting the masses viewed Che and his group as suspicious. ${ }^{56}$ The argument put forth is that the nucleus of the group was diverse, but did not contain any Bolivians from the operating area. It is true that there were Bolivians in Che's group, but they were from outside of the initial operating zone.${ }^{57}$ Che's own book states, "combatant nucleus of the guerrilla army ought to be made up of peasants. ${ }^{\prime 58}$ Considering the group lacked any local representation, it was inevitable that the local populace would view them as foreigners. ${ }^{59}$ It has been argued that these feelings compelled the local populace to support the Bolivian army ${ }^{60}$, but also causing the desertion of several guerrillas in Che's group ${ }^{61}$. The conclusion then is that Che was poised to most certainly fail from the start as he would be unable to gather the mass support required to fulfill his guerrilla vision in Bolivia.

\section{Failures in Strategy}

An obvious failure in strategy again is based on Che's writing in "Guerrilla Warfare". In the guerrilla strategy section of his book, Che states "At the outset, the essential task of the guerrilla fighter is to keep himself from being destroyed." ${ }^{\prime 2}$ It is self-explanatory that this strategic objective was not achieved by Che. It is argued that this is partly to blame on another strategic mistake, which is a lack of a strong fortified base of operations. ${ }^{63}$ Che and his guerrilla group were preparing to accomplish this task, but were prevented from doing this largely to the early detection of their presence. They were unable to fully establish any such base or an alternate $^{64}$, and further more were unable to establish supply routes to ensure the guerrilla band could be resupplied ${ }^{65}$. With no safe haven, almost non-existent support from the local populace, the guerrilla band was forced to continuously move causing them to weaken ${ }^{66}$ This would eventually allow the Bolivian army to encircle the guerrilla group and nearly decimate it. 
Part of the guerrilla failure lies in their poor strategic communications. In Che's book, “Guerrilla Warfare”, he talks about civil organization. Within the civil organization of the insurrectional movement Che states there are two important fronts, the external and the internal. ${ }^{67}$ Some argue that Che's group failed on the external front to convey propaganda of the national, orienting type. ${ }^{68}$ This has been credited to the swift action taken by the Bolivian government to repress the guerrilla civil organization apparatus upon discovery. ${ }^{69}$ Furthermore, the Bolivian government cut off any support from political or labor leaders by either imprisoning them, or restricting their movement. ${ }^{70}$ Che also states in his book that the most effective propaganda is produced in the actual zone of operations. ${ }^{71}$ This effort produced no tangible results for Che's group, and it has been further argued that Che's group actually evoked fear in the local populace as Che and the guerrillas were viewed as outsiders. ${ }^{72}$ On a lesser scale, it has also been suggested that there existed even basic language barriers that prevented fruitful communication. ${ }^{73}$ Combining all these issues and one can clearly see that Che's group either did not or was unable to establish the necessary strategic communication it required to support its operations.

Another seeming strategic misstep was Che's certainty of the response by the United States. As previously addressed, Che's inspiration was the development of a second or third Vietnam in Latin America. ${ }^{74}$ In this same message Che implies that in Latin America the United States "monopoly capital holds absolute primacy." 75 He continues by suggesting that certain Latin American governments are puppets of the United States, which has reached a highpoint of political and economic supremacy in Latin America. ${ }^{76}$ One concludes by these statements then, that Che believed that the United States was so invested in Latin (South) America, that any threat 
to this economic or political power would invoke a United States response. It has been argued that Che erred on his assumptions of the United States response.

It is suggested that Che believed the United States would first send advisors to be followed by combat units, similar to the escalation in Vietnam. ${ }^{77}$ The United States instead chose to send Special Forces to Bolivia to provide training to specific units of the Bolivian army with the intentions of enabling the Bolivian forces to address the guerrilla situation. ${ }^{78}$ Some argue that this unforeseen response by Che contributed to his failure in Bolivia. ${ }^{79}$ It would seem that Mr. Rostow, President Johnson's National Security Advisor, shared this sentiment when he wrote a memorandum to the President on 11 October 1967 expressing, "It shows the soundness of our [preventative medicine] assistance to countries facing incipient insurgency."

\section{Failures in Tactics}

Compounding to the failures in theory and strategy were the tactical miscues. One argument that has been presented is that Che violated the principle of security multiple times. ${ }^{81}$ It can be further argued that this was a lack of discipline on Che and the guerrilla group's part. One such argument is that by failing to establish an alternate base, the guerrillas were left with no safe shelter. ${ }^{82}$ This presented them a security issue as their main base camp was easily accessible. ${ }^{83}$ Another example was pictures confiscated in several captured guerrilla rucksacks provide the necessary evidence for Bolivian authorities to dismantle the guerrillas' underground urban mechanism. ${ }^{84}$ This tactical blunder will be discussed further in the following paragraph. Similarly Che allowed new recruits too liberal of access to sensitive information which became a liability as some of these recruits deserted and were captured by Bolivian forces. ${ }^{85}$ These brief examples highlight, as it has been argued, failure to adhere to the principle of security which seemingly appears to stem from lack of discipline within the guerrilla band. ${ }^{86}$ 
Another argument presented was that Che's guerrillas failed to establish communications lines outside the operations area ${ }^{87}$ This would include placing trustworthy people at intermediary points to ensure the safeguarding of stored supplies and a safe haven for guerrillas if required. ${ }^{88}$ Failing to establish these communications lines would bean failure in resupply, especially during unforeseen circumstances. ${ }^{89}$ The establishment of the critical logistics network was prevented first of all by the early detection of the guerrilla band. ${ }^{90}$ The premature detection, combined with the dismantling of the guerrilla's urban mechanism discussed in the previous paragraph, the guerrillas were forsaken to whatever supplies they could muster within the operations zone. This proved most challenging to the guerrillas as most basic necessities were scarce in the operations zone. ${ }^{91}$

The guerrillas made several attempts to scrounge resources, mainly by tactical incursions into small villages or cities within the operating zone. Several surprise incursions took place into villages or cities that contained, or were near, critical lines of communication for Bolivia, such as railways and highways. This presented the guerrillas with several opportunities to exploit weak points of their enemy. To the surprise of some however, this never occurred. The argument is that because Che and the guerrillas failed to capitalize by exploiting these weaknesses, thus forcing the Bolivian army to split its forces to safeguard other weak points, the guerrillas allowed the Bolivian army instead to continue their pursuit of the guerrillas. ${ }^{92}$ Instead of potentially straining and weakening the Bolivian army, Che and the guerrillas actually provided relief when they failed to exploit the weak points and left the area. ${ }^{93}$ This was counterintuitive to what Che states in his "Guerrilla Warfare" book, "One of the weakest points of the enemy is transportation by road and railroad." 94 The failure to capitalize may be attributed to another tactical mistake. 
Not long after the guerrilla band had been exposed, after several bouts with the Bolivian army, Che made a tactical decision to split his already small guerrilla band into two entities. This decision directly conflicted with Che's previous thoughts that the guerrilla force should never be divided. ${ }^{95}$ Although the split was only meant to be temporary, the group never again united due largely to Che's failure to designate a meeting point. ${ }^{96}$ Adding to an already worsening situation was Che choosing to move into an area that was unfamiliar to the guerrilla band.${ }^{97}$ Although both groups evaded Bolivian forces for four months while working to link up, it has been argued that their separating not only weakened them, but also enabled the Bolivian army to eradicate them in parts. ${ }^{98}$ One can attribute this tactical misjudgment to another tactical error that in the end cost Che not only his freedom, but also his life.

Che stresses in his book "Guerrilla Warfare" that a fundamental trait of the guerrillas is mobility.${ }^{99}$ He states that this not only allows guerrillas to change the front, but also to avoid encirclement by enemy forces. ${ }^{100}$ Che also stated that the tactics of guerrilla warfare required "good knowledge of the surrounding countryside." 101 One deduces that Che believed in these tactical fundamentals as they supported his strategy of ensuring the survival of the guerrilla fighters. Unfortunately for Che and the guerrillas that accompanied him, he failed to avoid encirclement by his "enemy", the Bolivian army. ${ }^{102}$ Although he eluded pursuit for many months, Che and his group struggled to determine where they were and where to go. ${ }^{103}$ This inevitably placed Che and is group into a disadvantageous tactical position in a canyon encircled by Bolivian army forces trained by United States Special Forces. ${ }^{104}$ This would be the last decision Che would make before his death. 


\section{Summary}

Drawing from the evidence presented, it is clear that Che and his supporters are guilty of multiple miscalculations and mistakes. Although his theories had worked in previous efforts, Che's perceptions of Bolivia may have been misconstrued and deceived him into seeing what he wanted to see. It must also be considered, based on many of Che's own writings that the passion he felt towards engaging the perceived imperialism of the United States may have misguided his decisions and forced miscalculations. This continued to erode forcing strategical mistakes. The most significant of these being the inability to facilitate the support desperately need from the masses. Support Che himself on numerous occasions in his book emphatically stated was of utmost importance. The error chain continued for Che and infected his decisions down to the tactical level. Although the argument has been made that Che's efforts were doomed to fail well before engaging in tactical events, Che continued to make mistakes and display poor judgment counterintuitive to his own book entitled "Guerrilla Warfare".

One therefore has to ask why a man who was well educated and experienced made decisions that clearly contradict his own ideas? Some have tried to answer this question, as is clear through the evidence that has been presented. These arguments focus on the mistakes in theory, strategy, and tactical levels. The arguments are sound from that perspective and are justified by the facts of the events that took place. But is it that easy? Can one really believe that Che, a man obviously studied in guerrilla warfare, could have made such elementary mistakes? Is there something more to the story? A closer look at the events and the man can reveal answers to such questions. 


\section{Finding the Root Cause}

Up to this point this paper discussed some of the more popular, or common, explanations as to why Che's attempted Bolivian revolution ended in failure. It is undeniable that these factors contributed to Che's failure, but they do not explain why an educated and experienced man such as Che made such elementary mistakes. Some authors, such as Gary Prado Salmon, provide reasons as to why they believe Che committed these mistakes in contrast his theories, but they fall short of linking these mistakes to one main cause. It is obvious many mistakes were made on Che's part, but one must ask is there a reason attributable to why Che made mistakes contradictory to his own theories on guerrilla warfare. The thesis presented at the beginning of this paper proposes that it was Che's pride, mainly his unrelenting belief in the use of revolutionary warfare, doomed his endeavor in Bolivia.

To illustrate how Che's pride contributed to his eventual failure, the following will examine a serious of events or relationships that would inevitably cause his failure. First to be examined his Che's distrustful and tension filled relationship with the Soviet Union. Che from the beginning had ideological or philosophical differences with the Soviet Union, to include differing views on economics, of the third world, and revolution to name a few. These differences would eventually cause him to leave Cuba in 1965. His experiences after his departure from Cuba are another telling reason that his pride would continue to betray him and lead him to Bolivia in 1966. Once in Bolivia, it would again be Che's pride that would blind him to reality of the situation, causing him to deviate from the principles of his guerrilla warfare manual. It would also cause him to make inaccurate assumptions, such as the United States response to his presence in Bolivia. These tensions would culminate in Bolivia for Che, causing him to make decisions that conflicted with his principles on guerrilla warfare. 


\section{Tension with the Soviet Union}

It is presumed that when most people think of the relationship the Soviet Union and Cuba established, specifically in the early to mid-1960's, that it was one void of strife or tension. It appears automatic to assume that because Cuba received significant support from the Soviet Union that there was no tension between the two. It is false to think this. There were numerous contentious issues between them. Many of the substantial sources of tension between the two states were not quelled by Che or his beliefs. One can draw conclusions that many of the issues the two states experienced were exaggerated by Che and his ideals. The following section will provide context around several of the significant issues in which Che played a considerable role.

\section{Soviet Policy toward Third World and Latin America}

To fully understand the importance of the tension between Che and the Soviet Union, it is first necessary to understand how each viewed the Third World. This view point, especially for Che, was critical to the decisions made by both parties. The disparity between Che and the Soviet Union would be the root cause of much of the tension between them. For Che his beliefs were deeply rooted in his early life experiences and supported by his study of Marxism. For the Soviets, their views were more strategically based on the Cold War with the United States. This topic is also important because if it was not for the Third World, Che and the Soviet Union may not have crossed paths in the same way history has recorded. It is also precisely these views that would ultimately doom Che in Bolivia in 1967.

It is commonly agreed upon that the end of World War II (WWII) ushered in the Cold War between the United States and the Soviet Union. A significant portion of the Cold War was the competition between the United States and Soviet Union for influence in Third World nations. History tells us that many Third World nations would ultimately become the battle 
grounds for the United States and Soviet Union through what has been termed proxy wars. The Soviet Union embraced this position as their belief was there were favorable trends to advance communism within some of these nations. ${ }^{105}$ Their perspective was shaped through three assumptions by Soviet leader Nikita Khrushchev. These assumptions where: Third World motivation for independence coupled with Soviet support could advance socialism or communism, that newly independent Third World nations were instinctively anti-imperialist, and that bourgeois national leaders, not the local communist parties, should lead national liberation movements or revolutionary struggles. ${ }^{106}$ Most of the Soviet Union's optimism of this foreign policy revolved around Africa, Asia and the Middle East. Little thought was given to Latin America.

The main reason the Soviets did not view Latin America with the same enthusiasm as other regions of the world, can be attributed to their belief that the United States was to invested in Latin America. The Soviet Union under Khrushchev had a concept coined "peaceful coexistence". ${ }^{107}$ This term, as described by Jacques Levesque's, implies that essentially the United States and Soviet Union could support regimes of their choice through whatever means each determines appropriate, so long as there is no direct intervention by either nation. ${ }^{108}$ This term essentially states the intent of the Soviet Union to engage in proxy wars. Despite this policy, the Soviet Union understood clearly that Latin America was the United States backyard and had no intent to involve itself openly, or through this policy. That was true up until 1959, when the Cuban Revolution had ousted Batista.

The Cuban Revolution gave the Soviet Union hope that it could finally penetrate Latin America and gain influence there. They urged existing Latin American communist parties, loyal to Soviet Communism doctrine, to support progressive governments who showed potential on 
the national liberation front. ${ }^{109}$ The Soviet Union policy for Latin America then appears to be one of caution and to the maximum extent possible to use peaceful means of obtaining power. They no doubt had an interest in not drawing the United States into any form of intervention from a perceived threat to its heavy economic interests in the region. This would not however, stop the Soviet Union from its attempts to expand its influence, or its trade relationships.

The Soviet Union, like the United States, unquestionably had a desire to expand trade. What nation would not want to find to markets to trade with. Latin America was new ground for the Soviets. The Cuban Revolution opened the door for them to expand their trade in this region. In 1965 the Soviet Union traded $\$ 157$ million and this would grow to $\$ 260$ million in $1968 .{ }^{110}$ The Soviet Union, despite its desire to limit economic aid to developing countries, would also extend millions of dollars in credits to Latin American countries in the 1960's. It is therefore reasonable to assume that the Soviet Union, looking to expand its influence, would in return expect these countries to accept a certain amount of Soviet influence, or one might say a certain level of obedience. Many of the Soviet Union's Third World views can be interpreted as more self-serving than doing good deeds for the country receiving the assistance. This is what Che would believe.

Che had a very contrasting view of the Third World, especially Latin America. Che viewed the world differently than the Soviet Union. Che believed that current struggle of the world did not exist between capitalism and communism, but between developed and underdeveloped countries. ${ }^{111}$ Che believed that both the capitalist (the United States) and the communist (the Soviet Union) both used the Third World to achieve their own objectives. Che implies these countries did not help these countries out of kindness or goodwill. Che did not believe man should exploit man. Che envisioned a Third World that would stop undercutting 
each other for the gain received by either capitalists or communists. As time elapsed, this belief would reach a boiling point for Che and would cause him to become more openly critical of the Soviet Union.

This is not to say Che completely disagreed with the Soviet Union, but where he did disagree, he did so vehemently. On such example is that of the bourgeois national leaders spearheading national liberation movements or revolutionary struggles. Che did not trust the bourgeois, saying in one of his writings, “...in Latin America at least, it is practically impossible to speak of liberation movements led by the bourgeoisie." ${ }^{" 12}$ Che continues by giving the impression that the national bourgeoisie is not to be trusted as they will likely betray their country. Che was adamant in is writings that national liberation movements or revolution struggle must be generated from the masses, specifically the peasantry. Overtime Che lost faith in the Soviet Union and felt they were improperly supporting Third World countries. Thus he began is open criticism of the Soviet Union.

In December 1964 in addressing the United Nations General Assembly, Che openly attacked the Soviet Union's foreign policy when he stated, "As Marxist we have maintained that peaceful coexistence among nations does not include coexistence between the exploiters and the exploited, the oppressor and the oppressed." ${ }^{.113}$ Che would more boldly criticize Soviet foreign policy in 1965 in Algiers at the Afro-Asian Solidarity Conference where he declared, "The socialist countries have the moral duty to liquidate their tacit complicity with the exploiting nations of the West." ${ }^{\text {114 }} \mathrm{He}$ would continue to push socialist nations to assist what he perceived to be exploited nations, such as Vietnam. Che, and Castro for that matter, would both be critical over the Soviet Union's underwhelming support for Vietnam. Adding to the rift between Che and the Soviet Union was their respective views on armed struggle. 


\section{Armed Struggle}

Che and the Soviet Union could not have been more distant from each other on their views of armed struggle. These differences were a constant source of tension between the Soviet Union and Cuba, as Che and Castro shared the same view. The Soviet Union was more tempered on the use of armed struggle, while Cuba and Che were much more extreme in the relevant use of armed struggle. The Soviet Union would energetically continue to restrain Cuba, Castro, and Che from pushing an agenda that included armed struggle.

Che and Castro without doubt believed in the validity of armed struggle. For if they did not, they could not declare what they had accomplished in Cuba in 1959 has legitimate. Che specifically called for continued armed struggle in Latin America. Che in an article he published in 1962 stated that guerrilla action was the only choice for Latin America. ${ }^{15}$ Che goes further as to call to arms all Latin Americans. ${ }^{116} \mathrm{He}$ insisted that revolutions do not have to wait for the conditions to be right, as the traditional communist parties were perpetuating. ${ }^{117}$ Che believed that the Cuban Revolution had proven that conditions do not have to be right to initiate a revolution. He also strongly believed that revolutions could start and be waged without the direction or control of an orthodox communist party, as the Cuban Revolution had. ${ }^{118}$ There is no doubt by the mid-to-late 1960's Che had become frustrated with the Soviet Union's attitude toward armed struggle, and had discontent for their support for more peaceful methods. In his 1967 letter to the Organization of Solidarity with the Peoples of Asia, Africa and Latin America (OSPAAAL), or the Tricontinental, Che displays his displeasure when he states in reference to Vietnam:

But also guilty are those who at the decisive moment, hesitated to make Vietnam an inviolable part of the socialist territory - yes, at the risk of a war of global scale, but also compelling the U.S. imperialists to make a decision. Also guilty are those who persist in a war of insults and maneuvers, begun quite some time ago by the representatives of the two biggest powers in the socialist camp. ${ }^{119}$ 
Che openly calling for armed struggle conflicted with the Soviet Union not just an ideological level. As the Soviet Union continued to expand its trade in Latin America, the potential for armed conflict could directly impact these endeavors. As stated earlier, the Soviet Union's trade interest had increased by over $\$ 100$ million in a three year period. ${ }^{120}$ It was in their economic interest to prevent disruption to this economic growth. Similarly, the Soviet Union was unwilling to risk their "peaceful coexistence" with the United States. The Soviets were content with their finally establishing influence and trade in Latin America, so long as direct conflict with the United States was avoided. Che's, and for that matter Cuba's, call for armed struggle in Latin America threatened the Soviet Union's interests. It appears as if they were able to subdue some of Cuba's extremism in this matter in the mid-1960's, but they were unable to accomplish the same with Che.

\section{Economic Views}

Another significant source of tension between Che and the Soviet Union came in the form of economic differences. The tension between Che and the Soviets was only exacerbated by the fact that the Soviet Union was heavily invested, financially, in Cuba. The strong financial backing of the Soviet Union undeniable compelled them to feel that they should have influence over the economics of Cuba. Their assumption however, would conflict directly with Che's. Che believed that the two most important issues facing Cuba in 1960 were political sovereignty and economic independence. ${ }^{121}$ Cuba's strive for economic independence, under the direction of Che, would be an enormous cause of tension with the Soviets.

To effectively highlight why this is a major source of contention, one must first understand the investment the Soviet Union made in Cuba. In 1960 the Soviet Union and Cuba enacted a trade agreement in which the Soviet Union agreed to purchase 425,000 tons of sugar in 
1960 and would purchase one million tons annually for a period of four years. ${ }^{122}$ The Cubans received 80 percent payment in the form of Soviet goods, to include oil, and 20 percent in currency. ${ }^{123}$ Cuba also received a $\$ 100$ million credit for the purchasing of industrial equipment. ${ }^{124}$ Overall the Soviet Union from 1961 to 1967 had invested approximately $\$ 2.025$ billion in assistance and approximately \$933 million in military equipment from 1961 to $1975 .{ }^{125}$ It is therefore easy to assume that with the financial investment the Soviet Union had with Cuba, the Soviets expected to have some influence with Cuban affairs. This is not how Che saw it.

In the time following the 1959 Cuban Revolution, Che would eventually be appointed the Minister of Finance and the President of the National Bank. ${ }^{126}$ Che had the complete trust of Castro and was granted the freedom to develop Cuba's economy. Che saw the future of Cuba quite differently than the Soviets had envisioned. Che's ideas conflicted directly with that of the Soviet Union. This may have been in part because Che viewed the Soviet economy as being managed by a privileged bureaucracy that rewarded managers based on their fulfilling production requirements. ${ }^{127}$ The main dispute Che had with the Soviet economy was that it relied on material incentives to motivate workers, instead of reinforcing the idea of the moral incentive. ${ }^{128}$ Che asserted that material incentives would bread corruption as the privileged leadership would develop political interests and goals that contrast with those of the working people. ${ }^{129}$ Che also claimed that the Soviet Union was lagging behind in technology because they relied on the old system of economic calculation. ${ }^{130}$

Che thus set out to institute an economic foundation that differed from that of the Soviet Union. One such way was Che's belief of centralized planning, which he felt would introduce better technology and processes to benefit all of Cuba. ${ }^{131}$ Che also pushed for a diversification in agriculture, attacking the single crop system in place, despite Soviet advice against this. ${ }^{132}$ Che, 
with Castro's approval, moved to rapidly industrialize Cuba. Again Soviet advisors pressed for Cuba to abandon industrialization due to cost and lack of a market for goods produced. ${ }^{133}$ Che would not be dissuaded however, and insisted that the Soviet Union, or other socialist countries, to finance Cuba's efforts to industrialize, and proclaimed that Latin America would be their market for exports as revolution spread. ${ }^{134}$ It became clear to Che in 1964 that his economic ideas suffered from enormous difficulties.

Che's failing policies caused the Soviets to pressure Cuba to be more responsible with their financial aid and caused Cuba to be further dependent of the Soviet Union. Neither of which sat well with Che. He was falling short of achieving on of the most important Cuban goals of economic independence. The Soviets, although gaining more influence on matters, where not overly joyed either. This further dependence by Cuba only increased the economic burden for the Soviet Union. ${ }^{135}$ Although Che was always one to openly criticize himself, it could not have been easy for him to repress his pride after having blatantly disregarded Soviet advice. With a weak and stagnate Cuban economy, coupled with Che's ideological differences with the Soviets on the Third World and armed struggle, something had to give or Cuba risked severing ties with their financier.

\section{Che's Departure}

By 1965 it was apparent that Che was frustrated. His views of the Third World compelled him to lash out. Che's speech at the 1965 Afro-Asian Conference, held in Algeria, was not just a verbal assault on the Soviet Union, but all socialist countries. Che demanded that socialist countries must pay to assist in developing countries on the road to liberation, as it is profound conviction of socialist to do so. ${ }^{136}$ Che also harshly criticized the socialist countries by call them "accomplices of imperialist exploitation" ${ }^{137}$ A point he emphasized when he clearly stated that 
socialist countries should unquestionably supply weapons to countries involved with an armed struggle for their liberation, without insisting on payment first. ${ }^{138}$ Little questions exists that Che understood the repercussions his speech would have.

When he returned to Cuba in March of 1965, Che had predetermined that he would resign his Cuban government posts. ${ }^{139} \mathrm{He}$ had reached his limit on frustration and was prepared to take up armed struggles wherever he was needed. This however did not resolve him from Castro admonishing him for his unfavorable comments towards socialist countries, including Cuba's benefactor the Soviet Union. Castro unequivocally informed Che there was enormous pressure, both internally and externally, for Cuba to side with the Soviet Union on the Sino-Soviet split. ${ }^{140}$ This pressure was most likely directly from the Soviet Union, who seemed to have gained more influence over Cuba over Che's disparaging comments towards all socialist countries. Che therefore came to the realization he must leave.

Che's departure seemed to be in the best interest of Cuba. His presence, especially has a top level government official, was very antagonistic due to his dispute with the Soviets on their foreign policy, Cuba's dependence on Soviet aid, and Che's unrelenting desire to reengage in armed struggle. ${ }^{141}$ Participation in armed struggle while employed as a Cuban government official, especially in the aftermath of Che's comments in Algeria and the Soviet Union's constant attempts to quell the armed struggle tendencies of Che and Castro, was not a risk to be taken. It was therefore decided Che would resign and leave for the Congo. Going to the Congo served several purposes. First, by Che leaving Cuba, and Latin America for that matter, would release some tension between Cuba and the Soviet Union. Second, it allowed Che to participate in an armed struggle for reasons that were at his core, defeating imperialism for one. The Congolese endeavor however, would end in failure for Che after only seven months. ${ }^{142}$ From this 
experience it appears to be unlikely that Che learned anything, for he would less than one year later embark on a similar adventure in Bolivia.

\section{Effects in Bolivia during 1967}

It is difficult to understand why Che was persistent on attempting another armed struggle less than one year after his failed efforts in the Congo. One can only say he deeply held onto his conviction that armed struggle was the only tactic that could truly free Latin America from imperialism is his eyes. It also been suggested that Che continued to believe he could free Cuba from its economic dependence of the Soviet Union by creating additional Latin American

revolutionary governments. ${ }^{143}$ After secretly returning to Cuba in 1965 , Che and Castro agreed it was time to attempt this dream in Latin America, despite the risks this could inflict on Cuba's relationship with the Soviet Union. After the decision had been reached, preparations began for the Bolivian campaign. Che would soon discover that his unbreakable adherence to his revolutionary ideology would have significant consequences to his Bolivian efforts.

\section{Bolivian Communist Party}

Although not discussed prior, it is important at this point to briefly discuss a divide within the communist parties. There essentially were two sides of communism that existed at the time. One side being that of the pro-Soviets, who as discussed prior believed in a more peaceful approach to assuming power, and would only resort to armed struggle once the conditions were perceived to be right. The other side consisted of the pro-Chinese, who believed that armed struggle was the way to achieve the desired objectives. It is obvious that Che was more aligned with the pro-Chinese side of the split. Not only was this divide a critical factor, but Che's pride was also damaging for his efforts as well. 
The Bolivian communist party was not immune to the effects of the communist divide. This combined with Che's distrust of pro-Soviet communists would create several significant issues for Che and his efforts. The first issue was Che received no support from the pro-Chinese communist, despite the fact they shared the same feelings toward armed struggle. ${ }^{144}$ This must have been expected since Che was obviously aligned with Cuba, and Cuba had by 1966 proclaimed his concurrence with the Soviet Union in the Sino-Soviet split. This factor is overlooked in works that discuss Che's failure in Bolivia. By not having the support of the proChinese communist, he lost items critical to his armed struggle. To only name a few, Che lost this organizations ability to provide intelligence, supplies, support communication, and recruits or fighters. These are all valuable resources to guerrilla fighters, especially those such as Che that are foreigners. The inability for the communist party to align both sides, without question was the reason Che was unable to garner any support for the pro-Chinese communist. In retrospect, the pro-Soviet communist did not do any better in this regard.

The pro-Soviet communist were at least initially engaged in supporting Che's Bolivian revolution. This support stemmed from an agreement between Castro and Mario Monje, a key figure in the Bolivian pro-Soviet communist party, during the 1966 Tricontinental conference held in Havana, Cuba. ${ }^{145}$ It would not take long for this arrangement to disintegrate. It has been suggested that the Bolivian pro-Soviet communist believed that Che and his fellow Cubans were being sent to Bolivia to support a Bolivian lead revolution. ${ }^{146}$ This pro-Soviet group was surprised to discover, after Che was in Bolivia, that this was not the case. The Bolivians were not pleased at the apparent deception. While in Bolivia, Che met with Monje on 31 December 1966. During this meeting, Monje presented Che with three conditions of his fundamental position, of which the second condition did not receive Che's approval. ${ }^{147}$ Monje told Che he was to lead the 
armed struggle in Bolivia, to which Che replied that he had to be military chief accepting nothing less. ${ }^{148}$ The following day the ties between the pro-Soviet Bolivian communist and Che's guerrilla band were severed. Che suggests that Monje appeared evasive and treacherous. ${ }^{149}$ Che further concluded that this party had now taken arms up against his guerrilla band potentially delaying his efforts, but it also freed him from political constraints. ${ }^{150}$

As Che was simultaneously dealing with the Bolivian pro-Soviet communist party, Castro received a visit from a top Soviet government official. In the fall of 1966 the General Secretary of the Central Committee of the Communist Party of the Soviet Union, Lenoid Brezhnev, criticized Castro for revolutionary activity in Latin America, especially the dispatching of Che to Bolivia. ${ }^{151}$ This cable suggests that the Soviets were well informed on Che's intents. It is therefore plausible that because the Soviets did not fully support armed struggle and the Bolivian pro-Soviet communist supported the Soviet Union, that the Soviet Union exerted influence on the Bolivian communist's decision on whether or not to support Che. This theory makes sense if you peel the onion back. The Soviet Union has already expressed the displeasure with Che and Castro endorsing armed struggle. The Soviet Union also had significantly expanded their trade in Latin America and was continuing its efforts to further expand it. The United States was showing growing interests in Latin America due to other failed armed struggles in Latin America, and showed willingness to intervene when it perceived the Cuban Revolution was spreading to the Dominican Republic in $1965 .{ }^{152}$ There is also another reason to assume Soviet involvement in Che's Bolivian campaign.

\section{A Spy Within}

Up to this point, one should have a clear understanding that the relationship between Che and the Soviet Union was strained at best due to fundamental differences. One such difference 
that remained throughout the 1960's was there views on armed struggle, as previously discussed. This issue simple comes down to the Soviet Union did not want it, but the Cubans, to include Che, couldn't stop pushing for it. Although the Soviets and Cuba reached a compromise by the mid-1960 on armed struggle, both remained pinned to their original position continuing to breed distrust. One can say then that distrust caused the Soviets to establish an intelligence network in Cuba. This network allowed Moscow to monitor the Cuban climate, and conduct operations if need be. Establishing an intelligence network would thus, at least theoretically, allow the Soviets the capability to place their agents where required. This leads to the story of Tania.

Tania was in Bolivia with Che, arriving over two years before him to prepare for his arrival. This is getting ahead of the story however, so it must begin with Tania's story. Tania's real name was Haydee Tamara Bunke, and was born in Argentina. ${ }^{153}$ Her parents were ardent communist, her mother having been born in the Soviet Union. At a young age Tania and family moved and settled in East Berlin in 1952. ${ }^{154}$ Here is East Berlin is where Tania would establish her own faith in communism, and at age 21 would be recruited by the East German Intelligence, who was essentially a satellite organization for the K.G.B. ${ }^{155}$ Tania's control officer was Oberleutnant Guenther Mannel, who defected in 1961, and would soon after provide the details of Tania to Chicago Tribune journalist, Daniel James.

Mannel confirmed that Tania first met Che in 1959 when she was assigned as his interpreter during his visit to East Berlin. ${ }^{156}$ It is suggested that Che was captivated by Tania, an Argentinean with Marxist ideals and of course attractive. In 1961 when the K.G.B. required someone to go to Cuba and watch Che, she seemed an obvious choice. Mannel confirms this in his interview with James as he said, "I myself assigned Tamara Bunke to Guevara as an agent." ${ }^{\prime 157}$ Tania arrived in Cuba mid-1961 and made quick work of building a close relationship 
with Che. It is this relationship that would ironically allow her to be trained as a Cuban spy in 1963. ${ }^{158}$ One can draw two conclusions from this brief history of Tania. First, clearly had connections to the Soviet Union, especially its intelligence apparatus. Second, she unquestionably was a well-trained operative, having been trained by East German Intelligence, the K.G.B. and the Cubans. It is with these two conclusions in mind that one must view here actions in Bolivia.

Tania arrived in Bolivia in 1964. She quickly established a relationship with Gonzalo Lopez Munoz, who would go on to be the chief of information for President Barrientos (Bolivian president). ${ }^{159}$ It was this connection that allowed Tania to arrange false paperwork for Che and the other guerrillas to gain entry into Bolivia. ${ }^{160}$ She also established herself with the Bolivian communist party, which would have introduced her to Monje discussed in the preceding section. Tania was also present at the meeting between Che and Monje on 31 December $1966 .{ }^{161}$ It was also at this meeting where Che clearly stated that Tania was never to return to the guerrilla camp, as it would risk the operation. She would fail to heed his advice.

Che had good reason to tell Tania to avoid the guerrilla camp. It is suggested that she displayed strange behavior, and poor judgement, by drawing unnecessary attention to herself. She even went so far as to joke with locals that her and her associates were guerrillas, which drew attention from the Bolivian army. ${ }^{162}$ She would also disobey Che's order not to return to the guerrilla camp when she would return accompanying Bustos and Regis Debray to the camp. ${ }^{163}$ It was from this trip where her arguably greatest mistake occurred. Tania drove a jeep, which was commonly known in the city of Camiri. She left this jeep in Camiri on this trip to the guerrilla camp, and it was ultimately search by Bolivian authorities. Inside the jeep, Bolivian authorities discovered a treasure trove of information on the guerrillas. The information gravely 
exposed the urban network in La Paz and left Che's guerrillas isolated. ${ }^{164}$ This resulted in an increased Bolivian army presence in the vicinity of the guerrilla camp which in-turn lead to the first guerrilla ambush beginning the battle between the Bolivian government and the guerrillas.

\section{The Connection}

It is now that we can start drawing some connections. To this point it has been made clear that Che and the Soviets had a distrustful relationship. The Soviet Union seemed to always be weary of Che, and it has been established that as early as 1961 the Soviet intelligence apparatus was assigning agents to monitor him. One main reason for this was over their differences in the validity of armed struggle. The Kremlin appears to have always believed Che to be the main inspiration for Cuba pushing this agenda. ${ }^{165}$ They had good reason to believe this. Che's strong belief in his ideals, especially those involving armed struggle, would make him uncompromising. It seems that the more the Soviets worked to temper these beliefs, the more strongly Che expressed them. His unwavering belief in armed struggle was not even shaken after his failed attempt in the Congo. With so much to loose from the Soviet perspective, increased diplomatic relations leading to increased trade in Latin America, it is not unthinkable that the Soviets would therefore have great interest in ensuring Latin America did not become consumed with revolution. Che's reputation and credibility within Latin America threatened these Soviet interests.

This makes it very plausible that the Soviet Union would have instructed Tania to ensure Che's Bolivian campaign did not succeed. If he were to succeed with his ambition to create a continental revolution, this threatened Soviet expansion through peaceful means. This would also explain why a person with Tania's training would make the mistakes that she had. In order to not expose herself, she tempered her behavior that drew just enough attention from the Bolivian 
authorities to monitor the situation. It also explains why a trained operative would leave such valuable and exposing intelligence in her jeep, which for some unknown reason was searched by local Bolivian authorities. Her early arrival in Bolivia also allowed her to establish contacts with the Bolivian communist party.

It is also plausible that the pro-Soviet Bolivian communist party was not only influenced by Tania, but by the other Soviet agents. This seems evident by the ultimatum that Monje received from the central committee of the Bolivian communist party. Monje, as previously mentioned had agreed to Cuban support for a Bolivian armed struggle, was given the ultimatum to either resign his position or have Che fall under party control. ${ }^{166}$ It has already been established that Che's pride and convictions would never have allowed him to surrender to party control. Thus all ties, and support, from the pro-Soviet Bolivian communist party was severed on 01 January 1967. It is following this, in March 1967, that Tania's jeep would be discovered, along with the intelligence it contained.

It is clear now that Che's convictions and pride were a main cause of the conflict between him and the Soviets. It is because of this that the Soviets willingly engaged in efforts to thwart any effort made by Che to incite armed struggle. For this reason, Che was unable to attain the critical elements he himself said necessary for guerrilla warfare to be successful. One of which would be the necessity of secrecy in the beginning to ensure the survivability of the guerrillas. As Che put it, "At the outset, the essential task of the guerrilla fighter is to keep himself from being destroyed." ${ }^{167}$ Tania appears to have ensured Che did not accomplish this task. Similarly, Che emphasized on numerous occasions that guerrilla warfare, revolution, is a struggle of the people. Che states in his guerrilla manual, “...that guerrilla warfare is a war of the masses, a war of the people." ${ }^{168}$ Che's convictions and pride drove his belief that the Cubans had to lead the 
Bolivian campaign, despite the many instances in his writings where he says the people of the affected nations must do this. This is because Che was less interested in Bolivia, versus establishing a continental revolution.

A reason for this may be his conviction that the Cuban economy could gain economic independence if more revolutionary governments were established in Latin America. Another explanation could be Che's pride and convictions were now driving him to not only want to defeat imperialism, but also now communism. By 1967 Che was not only espousing that capitalist were exploiting man, but that communism was exuding the same tendencies. One could argue many reasons, but the evidence seems to support that Che was not going to relinquish his ambitions to engage in armed struggle in Latin America, and the hopes of establishing a continental revolution. It is because of this deep belief that outside forces seemingly conspired against his success. This outside influence also drove many of the mistakes made in Bolivia at the more tactical level. In the end however, Che's strict adherence to his beliefs set in motion an irreversible series of events that would drive his divergence from his theories, and would ultimately end with his failure and death.

\section{United States Response}

Another example that demonstrates how Che's passion induced a miscalculation is in regards to the United States response to the emerging insurrection in Bolivia. Che expressed his anticipated United States response in an undated message to the Tricontinental, which was published in April 1967. Che stated in this message that he expected that as revolutionary activity increased in Latin America, that these activities would begin to overwhelm military forces despite the presence of United States advisors. ${ }^{169}$ Che, using Vietnam as the example, therefore concluded that the United States would be forced to increase its level of troops in order 
to combat the revolutionary activity. The presence of more United States troops was exactly what Che was hoping for. This concept may on the surface appear ludicrous, but Che had his reasons for wanting this.

Che did not fear an increase in United States troops, as he believed it to be a means to an end. Che, seeing how the events in Vietnam were unfolding in the mid to late 1960's, deduced that the way to defeat a skilled army, such as that of the United States, was to force it to fight where it is least comfortable doing so. His theory revolved around weakening the morale of such an army. Che believed that this type of army, specifically referring to the United States, suffered from a lack of "ideological motivation". ${ }^{170}$ As such Che expressed his desire for Latin America to create "...the world's second or third, or second and third Vietnam."171 Unfortunately for Che, the United States decided upon a different approach.

Despite Che's desire to entice the United States into another Vietnam type conflict, the United States deliberately selected a far less direct approach. The decision was made to use the combined efforts of diplomacy, military advisors, and the Central Intelligence Agency (CIA). Through diplomacy the United States was able to ensure that Che's ambition to spread guerrilla activity outward from Bolivia never came to fruition. Critical in supporting diplomatic works was the deployment of military advisors with the mission of training a selective group of Bolivian soldiers in counter-insurgency operations. Correspondingly, through assessments conducted, the CIA sent two agents to Bolivia to bridge identified intelligence gaps. Despite similarities with varying efforts in Vietnam, the efforts in Bolivia achieved different results.

Although one could spend much time describing the role diplomacy played in Bolivia in 1967, the following will focus primarily on United States diplomatic efforts to ensure it did not became snared within Che's vision. Critical to these efforts was the United States ambassador to 
Bolivia, Douglas Henderson. Henderson contributed in two significant ways. One way was his shared hesitation for substantial United States involvement. It has been stated that Henderson “...realized intuitively that the guerrilla leader, whether Guevara or not, wanted the United States enmeshed in a Vietnam-style conflict." ${ }^{172}$ He supported Washington's sentiment that the United States would not commit large numbers of troops, but also further believed that Bolivia was capable and should be out front leading counter-insurgent efforts. This leads to the second important contribution Henderson made.

Early after it learned of potential guerrilla activity, the Bolivian government began requesting greater military assistance, specifically in military equipment and armament, from the United States. From the onset of these requests, which included items such as high-performance aircraft and napalm, Henderson believed Bolivia was using the emerging insurgency to simply update their military equipment. ${ }^{173}$ Although there may exist truth to this belief, Henderson's efforts to deny such requests for items such as napalm, also contributed to limiting Bolivia's response to guerrilla activity. If Bolivia was allowed to use high-performance aircraft or napalm in their attempts to quell the guerrillas, they may have only succeeded in turning segments of the population against them. Henderson intentionally or not, most likely did the Bolivian government a great service not only by denying such equipment request, but by also supporting the employment of United States military advisors.

Ironically the Bolivian government had resisted multiple attempts by the United States to engage in Foreign Internal Defense (FID) operations. It was not until the emergence of a credible insurgent threat, and arguably the United States denial of Bolivian requests for military equipment, that Bolivia finally accepted United States offer. The United States then mobilized a military training team, comprised of Green Berets, to go to Bolivia and train a Ranger battalion 
in counter-insurgency operations. Leading this 16-man team was Maj Ralph "Pappy" Shelton. Shelton and his team were instrumental in instilling confidence in an army made up of mostly one year conscripts before this venture. Shelton's team ultimately trained the unit that would capture Che. Vital to this effort was Shelton's influence over Gary Prado Salmon, a company commander in the newly organized Bolivian Ranger battalion. These attempts were critical in not only enable the Bolivians to address the insurgency themselves, but also demonstrated external their capability to do so. Contributing to this capability was vital intelligence.

Shelton and his team as part of their training instilled in their Bolivian counterparts the criticality of intelligence. However, the most significant successful intelligence contributions came from CIA lead work, specifically from that of Felix Rodriguez. Rodriguez, a Cuban exile from the fallout of the 1950's Cuban Revolution, almost immediately upon arrival in Bolivia set out to improve intelligence operations, especially with regards to coordinating operations. ${ }^{174}$ Through his diligent efforts Rodriguez also identified the key guerrilla he would like to question if ever possible, Paco. ${ }^{175}$ Rodriguez eventually was granted his wish when Paco was captured. Through his interrogation of Paco, along with other research, Rodriguez was able to anticipate Che's movement and thus initiate the employment of the newly trained Bolivian Rangers. Ultimately the integration of United States trained Bolivian Rangers with United States lead intelligence efforts were too much for Che and his guerrilla band. A miscalculation he would only have to live with for a short time.

\section{Conclusion}

Many theories have been put forth as to the reasons Che failed in is 1967 attempted revolution in Bolivia. Many of the reasons suggested are correct, but only appear to be contributing factors versus the root cause for Che's failure. There clearly had to be something 
more to explain how an experienced and educated guerrilla fighter failed. It is this intent that drove the purpose of this paper and why it therefore purposes that root cause of Che's failure was his unbreakable adherence to his revolutionary ideology, or pride. It seems a rather simple answer. This is true, but it had devastating effects for Che. It created a distrustful relationship with the Soviet Union. Che's inability to accept advice from Soviet advisors because of his deep convictions, were nearly catastrophic for Cuba, especially the economy. His revolutionary ideology, specifically on armed struggle, placed him under Soviet scrutiny as early as 1961. These strains eventually forced him to resign from his Cuban Government positions, and drove him to the Congo. The Congo is another example of how deep his beliefs ran. It showed that even after experiencing failure in the Congo, Che continued in his quest to incite armed struggle by going to Bolivia. It is in Bolivia where his unwavering beliefs doomed him.

Che was clearly threatening Soviet interests in Latin America, especially with his ambitions of a continental revolution. This combined with the ideological differences between Che and the Soviet Union compelled the later to engage in activities to prevent Che's success. This is evident through the Soviet Union assigning an intelligence agent to directly monitor Che. Furthermore the Soviets used this same agent to ensure Che's efforts in Bolivia would not succeed. Similarly the Soviet Union influenced the actions of the pro-Soviet Bolivian communist party. Both actions on behalf of the Soviet Union made not only Che's success impossible, but made it impossible for him to accomplish the fundamental principles he set forth in his guerrilla manual.

Although Che's ideological devotion drove the most significant confrontation with the Soviet Union, it cannot be understated how grossly Che misjudged the United States' response to his Bolivian activities. Che assumed the United States would react in a similar fashion as it did to 
Vietnam. The United States however chose a less intrusive response. The United States response revolved around counter-insurgency operations through the use of FID. Diplomacy played a significant role, however in the end it was the combination of United States trained Bolivian Rangers acting on United States lead intelligence that would enable the Bolivians to corner, capture, and ultimately execute Che. It is valid to think that Che failed because of his actions in Bolivia in 1967, however the evidence presented suggests that Che began the failure chain long before. His unwavering passion for revolution through armed struggle seemingly forced him to make decisions counterintuitive to his own guerrilla manual. It can therefore be concluded, that Che was his own worst enemy. 


\section{ENDNOTES}

1. WS/LW Lecture, ACSC.

2. Guevara, Ernesto Che Guevara: The Bolivian Diary, XIV-XVI.

3. Ibid., XX-XXII.

4. Salmon, The Defeat of Che Guevara, XI. In the forward written by Lawrence Hall, he describes a continental "foco". "... as a base of operations for a guerrilla led revolution..."

5. Macias, Counter Guerrilla Operations in Bolivia 1967, 4, and Saldana, Fertile Ground: Che Guevara and Bolivia, 40.

6. Saldana, Fertile Ground: Che Guevara and Bolivia, 23.

7. Salmon, The Defeat of Che Guevara, 14.

8. Macias, Counter Guerrilla Operations in Bolivia 1967, 6.

9. Ibid., 4.

10. Salmon, The Defeat of Che Guevara, 15.

11. Ibid., 16.

12. Macias, Counter Guerrilla Operations in Bolivia 1967, 7.

13. Ibid., 7.

14. U.S. Department of State, Intelligence Note: Guevara's Death-The Meaning for Latin America, 3.

15. Salmon, The Defeat of Che Guevara, 240.

16. Ibid., 21.

17. Ibid., 23.

18. Macias, Counter Guerrilla Operations in Bolivia 1967, 9.

19. Ibid., 9.

20. Ibid., 11.

21. Ibid., 11. General Porter was the Commander of Southern Command.

22. Salmon, The Defeat of Che Guevara, 43.

23. Guevara, che guevara reader: writings on politics \& revolution, 358.

24. Ibid., 357.

25. Salmon, The Defeat of Che Guevara, 44.

26. Ibid., 44.

27. Ibid., 44.

28. Saldana, Fertile Ground: Che Guevara and Bolivia, 47.

29. Ibid., 46.

30. Waghelstein, A Theory of Revolutionary Warfare and Its Application to the Bolivian Adventure of Che Guevara, 37.

31. Guevara, Guerrilla Warfare, 15.

32. Macias, Counter Guerrilla Operations in Bolivia 1967, 13.

33. Ibid., 13.

34. Salmon, The Defeat of Che Guevara, 224.

35. Ibid., 224.

36. Ibid., 224.

37. Macias, Counter Guerrilla Operations in Bolivia 1967, 13.

38. Salmon, The Defeat of Che Guevara, 224.

39. Ibid., 224.

40. Macias, Counter Guerrilla Operations in Bolivia 1967, 15. 
41. Guevara, Guerrilla Warfare, 16.

42. Macias, Counter Guerrilla Operations in Bolivia 1967, 15.

43. Salmon, The Defeat of Che Guevara, 225.

44. Guevara, Guerrilla Warfare, 17.

45. Salmon, The Defeat of Che Guevara, 225.

46 Ibid., 225.

47. Waghelstein, A Theory of Revolutionary Warfare and Its Application to the Bolivian Adventure of Che Guevara, 38.

48. Saldana, Fertile Ground: Che Guevara and Bolivia, 49.

49. Ibid., 52.

50. Guevara, The Bolivian Diary, 58-59.

51. Ibid., 59.

52. Salmon, The Defeat of Che Guevara, 226.

53. Waghelstein, A Theory of Revolutionary Warfare and Its Application to the Bolivian Adventure of Che Guevara, 41.

54. Ibid., 41.

55. Pan American Union, Special Consultative Committee on Security, Study of the "Diary of

'Che' Guevara in Bolivia”, 17.

56. Waghelstein, A Theory of Revolutionary Warfare and Its Application to the Bolivian Adventure of Che Guevara, 42.

57. Ibid., 42.

58. Guevara, Guerrilla Warfare, 48.

59. Waghelstein, A Theory of Revolutionary Warfare and Its Application to the Bolivian Adventure of Che Guevara, 42.

60. Ibid., 42.

61. Macias, Counter Guerrilla Operations in Bolivia 1967, 15.

62. Guevara, Guerrilla Warfare, 21.

63. Salmon, The Defeat of Che Guevara, 227.

64. Ibid., 228.

65. Macias, Counter Guerrilla Operations in Bolivia 1967, 18.

66. Salmon, The Defeat of Che Guevara, 228.

67. Guevara, Guerrilla Warfare, 83.

68. Ibid., 86.

69. Salmon, The Defeat of Che Guevara, 231.

70. Ibid., 231.

71. Ibid., 232.

72. Ibid., 232.

73. Waghelstein, A Theory of Revolutionary Warfare and Its Application to the Bolivian Adventure of Che Guevara, 41.

74. Guevara, che guevara reader: writings on politics \& revolution, 358.

75. Ibid., 354.

76. Ibid., 354.

77. Waghelstein, A Theory of Revolutionary Warfare and Its Application to the Bolivian Adventure of Che Guevara, 46.

78. Salmon, The Defeat of Che Guevara, 23. 
79. Waghelstein, A Theory of Revolutionary Warfare and Its Application to the Bolivian Adventure of Che Guevara, 46.

80. Rostow, Death of "Che" Guevara, 1.

81. Waghelstein, A Theory of Revolutionary Warfare and Its Application to the Bolivian Adventure of Che Guevara, 47.

82. Ibid., 47.

83. Ibid., 47.

84. Ibid., 47.

85. Ibid., 47.

86. Ibid., 47.

87. Salmon, The Defeat of Che Guevara, 229.

88. Ibid., 229.

89. Ibid., 229.

90. Ibid., 229.

91. Ibid., 229.

92. Ibid., 228.

93. Ibid., 228.

94. Guevara, Guerrilla Warfare, 27.

95. Macias, Counter Guerrilla Operations in Bolivia 1967, 19.

96. Ibid., 19.

97. Salmon, The Defeat of Che Guevara, 230.

98. Ibid., 231.

99. Guevara, Guerrilla Warfare, 24.

100. Ibid., 24.

101. Ibid., 17.

102. Salmon, The Defeat of Che Guevara, 177.

103. Macias, Counter Guerrilla Operations in Bolivia 1967, 16.

104. Salmon, The Defeat of Che Guevara, 177-179.

105. Duncan, The Soviet Union and Cuba: Interests and Influence, 26.

106. Ibid., 27.

107. Levesque, The USSR and The Cuban Revolution: Soviet Ideological and Strategical Perspectives, 1959-77, 4.

108. Ibid., 4.

109. Ibid., 4, and Duncan, The Soviet Union and Cuba: Interests and Influence, 29.

110. Duncan, The Soviet Union and Cuba: Interests and Influence, 60.

111. Sinclair, Che Guevara, 87.

112. Guevara, Che Guevara Reader: Writings on Politics \& Revolution, 170.

113. Sinclair, Che Guevara, 88.

114. Ibid., 89.

115. Guevara, Che Guevara Reader: Writings on Politics \& Revolution, 302.

116. Ibid., 304.

117. Sinclair, Che Guevara, 47.

118. Harris, Death of a Revolutionary, 48.

119. Guevara, Che Guevara Reader: Writings on Politics \& Revolution, 353.

120. Duncan, The Soviet Union and Cuba: Interests and Influence, 60. 
121. Guevara, Che Guevara Reader: Writings on Politics \& Revolution, 99.

122. Shearman, The Soviet Union and Cuba, 8.

123. Ibid., 8 .

124. Levesque, The USSR and The Cuban Revolution: Soviet Ideological and Strategical Perspectives, 1959-77, 14.

125. Duncan, The Soviet Union and Cuba: Interests and Influence, 38-39.

126. Anderson, Che Guevara, 446.

127. Riddell, Che Guevara's Final Verdict on the Soviet Economy. 1.

128. Ibid., 2.

129. Ibid., 2.

130. Ibid., 3-4.

131. Sinclair, Che Guevara, 68-69.

132. Ibid., 77.

133. Harris, Death of a Revolutionary, 68-69.

134. Ibid., 68-69.

135. Levesque, The USSR and The Cuban Revolution: Soviet Ideological and Strategical

Perspectives, 1959-77, 22.

136. Guevara, Che Guevara Reader: Writings on Politics \& Revolution, 341.

137. Harris, Death of a Revolutionary, 72.

138. Guevara, Che Guevara Reader: Writings on Politics \& Revolution, 347.

139. Harris, Death of a Revolutionary, 72.

140. Ibid., 72.

141. Ibid., 73 .

142. Ibid., 81 .

143. Ibid., 86.

144. Ibid., 94.

145. Ibid., 89.

146. Salmon, The Defeat of Che Guevara, 233.

147. Guevara, The Bolivian Diary, 58-59.

148. Ibid., 58-59.

149. Ibid., 78.

150. Ibid., 60 and 78.

151. Central Intelligence Agency. Intelligence Information Cable Number 94-455.

152. Levesque, The USSR and The Cuban Revolution: Soviet Ideological and Strategical Perspectives, 1959-77, 109.

153. Daniel James, "The girl who betrayed che Guevara." chicagotribune.com, 21 September 1969. http://archives.chicagotribune.com/1969/09/21/page/259/article/the-girl-who-betrayedche-guevara.

154. Ibid.

155. Ibid.

156. Ibid.

157. Ibid.

158. Ryan, The Fall of Che Guevara, 67.

159. Ibid., 67.

160. Ibid., 68. 
161. Ibid., 69.

162. Daniel James, "The girl who betrayed che Guevara." chicagotribune.com, 21 September 1969. http://archives.chicagotribune.com/1969/09/21/page/259/article/the-girl-who-betrayedche-guevara.

163. Ibid.

164. Ryan, The Fall of Che Guevara, 69.

165. Daniel James, "The girl who betrayed che Guevara." chicagotribune.com, 21 September 1969. http://archives.chicagotribune.com/1969/09/21/page/259/article/the-girl-who-betrayedche-guevara.

166. Ryan, The Fall of Che Guevara, 65.

167. Guevara, Guerrilla Warfare, chapter 1, section 2 Guerrilla Strategy.

168. Ibid., chapter 1, section 1, Essence of Guerrilla Warfare.

169. Guevara, Che Guevara Reader: Writings on Politics \& Revolution, 358.

170. Ibid., 359.

171. Ibid., 358.

172. Ryan, The Fall of Che Guevara, 53.

173. Ibid., 46.

174. Weiss and Maurer, Hunting Che: How a U.S. Special Forces Team Helped Capture the World's Most Famous Revolutionary, 135-136.

175. Ibid., 136. 


\section{Bibliography}

Anderson, Jon Lee. Che Guevara: A Revolutionary Life. New York: Grove Press, 1997.

Central Intelligence Agency. Intelligence Memorandum Number 2333/65. Washington, DC:

Central Intelligence Agency, Directorate of Intelligence, 18 October 1965. Document is now declassified.

Central Intelligence Agency. Intelligence Information Cable Number 94-455. Washington, DC: Central Intelligence Agency, October 1967. Document is now declassified.

Chief, USARSEC/MILGF. To Commander, Bolivian Army. To Commander, Bolivian Armed Forces. Memorandum of understanding, 28 April 1967.

Debray, Regis. Revolution in the Revolution?: Armed Struggle and Political Struggle in Latin America. New York and London: MR Press, n.d.

Dotto, Lt Col Peter A. "Defeating Guerrilla Warfare.” Naval War College, 1991.

Duncan, W. Raymond. The Soviet Union and Cuba: Interests and Influence. New York: Praeger Publishers, 1985.

Guevara, Che. che guevara reader. North Melbourne, Australia: Ocean Press, 2013.

Guevara, Che. Guerrilla Warfare. New York: Monthly Review Press, 1961.

Guevara, Ernesto Che. The Bolivian Diary. Melbourne, Australia: Ocean Press, 2006.

Harris, Richard L. Death of a Revolutionary: Che Guevara's Last Mission. New York: W.W. Norton \& Company, Inc., 2007.

Huberman, Leo and Sweezy, Paul M. Socialism in Cuba. New York: Monthly Review Press, 1969.

James, Daniel. "The girl who betrayed che Guevara.” chicagotribune.com, 21 September 1969. http://archives.chicagotribune.com/1969/09/21/page/259/article/the-girl-who-betrayedche-guevara.

Labedz, Leopold and Urban, G.R. The Sino-Soviet Conflict. Chester Springs, PA: Dufour Editions, 1965.

Levesque, Jacques. The USSR and the Cuban Revolution: Soviet Ideological and Strategical Prespectives, 1959-77. New York: Praeger Publishers, 1978.

Lowy, Michael. The Marxism of Che Guevara: Philosophy, economics, and revolutionary warfare. New York: Monthly Review Press, 1973.

LW-518. Leaders in Irregular Warfare. Maxwell AFB: ACSC, 2014.

Macias, Col Carlos M. "The Counter Guerrilla Operations in Bolivia - 1967: An Individual Study Project.” USAWC Military Studies Program Paper. Carlisle Barracks, PA: U.S. Army War College, 1988.

Pavlov, Yuri. Soviet-Cuban Alliance: 1959-1991. Coral Gables, Florida: University of Miami North-South Center, 1994.

Reynolds, Steve and Carver, Gene. The Murder of Che Guevara. Soddy Daisy, TN: The Wild Geese Publishing Co., 1983.

Riddell, John. "Che Guevara's Final Verdict on the Soviet Economy." Global Research, 2008. http://www.globalresearch.ca/che-guevara-s-final-verdict-on-the-soviet-economy-9315.

Rostow, W.W. National Security Advisor. To the President of the United States. Memorandum, 11 October 1967.

Ryan, Henry Butterfield. The Fall of Che Guevara. New York: Oxford University Press, 1998. Saldana, Rodolfo. Fertile Ground: Che Guevara and Bolivia. New York: Pathfinder, 1997. Salmon, Gary Prado. The Defeat of Che Guevara. New York: Praeger Publishers, 1990. 
Sauvage, Leo. Che Guevara: The Failure of a Revolutionary. Englewood Cliffs, New Jersey: Prentice-Hall, Inc., 1973.

Shearman, Peter. The Soviet Union and Cuba. New York: Routledge \& Kegan Ltd., 1987.

Sinclair, Andrew. Che Guevara. New York: The Viking Press, 1970.

Study of the "Diary of 'Che' Guevara in Bolivia". Washington, DC: Pan American Union, Special Consultative Committee on Security, November 25 - December 20, 1968.

U.S. Department of State. Intelligence Note: Guevara's Death-The Meaning for Latin America. Washington, DC: U.S. Department of State, Director of Intelligence and Research, 12 October 1965. Document is now declassified.

U.S. Department of State. Airgram Number A-128. Washington, DC: U.S. Department of State, 18 October 1967. Document is now declassified.

Villegas, Harry. Pombo a man of Che's Guerrilla: with Che Guevara in Bolivia 1966-68. New York: Pathfinder Press, 1997.

Waghelstein, John David. "A Theory of Revolutionary Warfare and Its Application to the Bolivian Adventure of Che Guevara." Master's Thesis, Cornell University, 1973.

Weiss, Mitch and Maurer, Kevin. Hunting Che: How a U.S. Special Forces Team Helped Capture the World's Most Famous Revolutionary. New York: The Berkley Publishing Group, 2013.

WS-520. Revolutionary War and Insurgency. Maxwell AFB: ACSC, 2014. 